Please do not remove this page

RMIT

UNIVERSITY

\title{
Project pathogens: The anatomy of omission errors in construction and resource engineering project
}

Love, Peter; Edwards, David; Irani, Zahir; Walker, Derek

https://researchrepository.rmit.edu.au/esploro/outputs/9921864096901341/filesAndLinks?institution=61RMIT_INST\&index=null

Love, P., Edwards, D., Irani, Z., \& Walker, D. (2009). Project pathogens: The anatomy of omission errors in construction and resource engineering project. IEEE Transactions on Engineering Management, 56(3), 425-435. https://doi.org/10.1109/TEM.2008.927774

Published Version: https://doi.org/10.1109/TEM.2008.927774

Repository homepage: https://researchrepository.rmit.edu.au

(c) 2009 IEEE. Personal use of this material is permitted. However, permission to reprint/republish this material for advertising or promotional purposes or for creating new collective works for resale or redistribution to servers or lists, or to reuse any copyrighted component of this work in other works must be obtained from the IEEE.

Downloaded On 2023/04/26 16:24:06 +1000 


\title{
Project Pathogens: The Anatomy of Omission Errors in Construction and Resource Engineering Project
}

\author{
Peter E. D. Love, David J. Edwards, Zahir Irani, and Derek H. T. Walker
}

\begin{abstract}
Construction and engineering projects are typically complex in nature and are prone to cost and schedule overruns. A significant factor that often contributes to these overruns is rework. Omissions errors, in particular, have been found to account for as much as $\mathbf{3 8 \%}$ of the total rework costs experienced. To date, there has been limited research that has sought to determine the underlying factors that contribute to omission errors in construction and engineering projects. Using data derived from 59 in-depth interviews undertaken with various project participants, a generic systemic causal model of the key factors that contributed to omission errors is presented. The developed causal model can improve understanding of the archetypal nature and underlying dynamics of omission errors. Error management strategies that can be considered for implementation in projects are also discussed.
\end{abstract}

Index Terms-Error, error management, omission, pathogens, rework.

\section{INTRODUCTION}

I $\mathrm{N}$ THE construction and resource engineering sector in Australia, particularly in Western Australia, a wide range of project types have commenced to meet the increasing demand for new infrastructure and resources, such as oil and gas, bauxite, copper, iron ore, and nickel. Such projects are typically complex and often prone to cost and schedule overruns [11]. A significant factor that often contributes to these overruns is rework [66]. While several definitions of rework are available within the literature, (e.g., [6], [23], [25], [69]), a common theme arising is that which relates to "the unnecessary of effort of redoing a process or activity that was incorrectly implemented the first time" [51]."

Design changes, errors, and omissions account for $79 \%$ of the total rework costs experienced in a project [13], but of this percentage, omissions errors alone account for $38 \%$ [77]. Omissions errors can be defined as failures to follow due procedure when undertaking a task(s). These are the single most common form of human error [65, p. 41]. Specifically, projects appear to progress smoothly until nearing completion, when such errors made earlier are discovered, necessitating costly rework [25], [30]. Such rework transpires as overtime, additional hiring of resources (including labor and plant), schedule

Manuscript received September, 2007; revised April, 2008. Current version published July 17, 2009. This work was supported by the Australian Research Council under Grant DP-0453258. Review of this manuscript was arranged by Department Editor J. K. Pinto.

P. E. D. Love is with the Department of Construction Management, Curtin University of Technology, Perth, W.A. 6845, Australia.

D. J. Edwards is with the Department of Civil and Building Engineering, Loughborough University, Loughborough, Leicestershire, LE11 3TU, U.K.

Z. Irani is with the Business School, Brunel University, Uxbridge UB8 3PH, U.K.

D. H. T. Walker is with the School of Property, Construction, and Project Management, RMIT University, Melbourne, VIC 3000, Australia.

Digital Object Identifier 10.1109/TEM.2008.927774 slippage, and reductions in project scope or quality [25]. The adverse consequences of these difficulties include reduced profit, loss of market share and reputation, increased turnover of management and workforce, lower productivity, higher costs, and, all too frequently, costly litigation between participants over responsibility for overruns and delays [1], [24], [30].

Omission errors are a result of pathogens within a system that translate into error provoking conditions within the firm and project (e.g., time pressure, understaffing, fatigue, and inexperience). These pathogens contribute to unworkable relationships and procedures as well design and construction deficiencies [64]. There has been a considerable amount of research that has examined the nature of human errors, its types, and causes in a range of areas such as aviation (e.g., [10], [38]), medicine (e.g., [62]), engineering design (e.g., [15]), and construction (e.g., [7], [8]), yet studies that explore the underlying conditions and factors that contribute to the occurrence of omission errors are limited. Using data derived from 59 in-depth interviews undertaken with various participants operating in the construction and resource engineering sector, a generic causal model of omission errors is developed. From the findings presented, error management strategies for reducing the incidence of omission errors are then discussed.

\section{Project Pathogens}

Pathogens are latent conditions [61] and lay dormant within a system until an error comes to light. Before they are apparent, project participants often remain unaware of the impact upon project performance that particular decisions, practices, or procedures can have [18]. Pathogens can arise because of strategic decisions taken by top management or key decisionmakers. Such decisions may be mistaken but they need not be. Latent conditions can lay dormant within a system for a considerable period of time and thus become an integral part of everyday work practices. However, once they combine with $a c$ tive failures (which are similar to Deming's common causes), then omission errors can arise and the consequences of which may be significant. Active failures are essentially unsafe acts committed by people who are in direct contact with a system. Such acts include: slips, lapses, mistakes, and procedural violations [64]. Active failures are often difficult to foresee, and therefore, cannot be eliminated by simply reacting to the event that has occurred. Latent conditions, however, can be identified and remedied before an adverse event occurs.

Pathogens have been defined by a number of qualities $[18$, p. 428].

1) They are a relatively stable phenomena that have been in existence for a substantial time before the error occurs. 
2) Before the error occurs, they would not have been seen as obvious stages in an identifiable sequence failure.

3) They are strongly connected to the error, and are identifiable as principal causes of the error once it occurs.

The pathogens that have been revealed to contribute to the occurrence of errors can be categorized as follows [18].

1) Practice — arising from people's deliberate practices.

2) Task - arising from the nature of the task being performed.

3) Circumstance - arising from the situation or environment the project was operating in.

4) Organization-arising from organizational structure or operation.

5) System - arising from an organizational system.

6) Industry - arising from the structural property of the industry.

7) Tool-arising from the technical characteristic of the tool.

Busby and Hughes [18] found that many pathogen-orientated errors in engineering firms were based on practices (i.e., those pathogens from people's deliberate practices) that attempted to solve a particular problem. For example, recycling design details, specifications, and other contract documentation to reduce time and save money without giving due considerations to the bespoke nature of construction projects. The practice of starting work on the basis of tentative information is often a consequence of working within the realm of nontraditional procurement methods (overlapping of activities), and therefore, short lead times are often needed to meet a project's schedule.

Individuals may repeat practices, such as taking short cuts and not following due processes. When a practice provides an outcome that is deemed to be satisfactory by the individual, then this practice is used on future projects even if it is unsuitable for that project [18]; for example, the decision by designers to eschew audits, checks, verifications, and reviews prior to releasing documentation for pricing or construction. Despite the importance of such activities, this practice has become a norm due to the financial and time pressures being imposed upon design firms by their clients. Tilley and McFallen [74] have suggested that there is a positive correlation between the demands imposed by clients for earlier completion of projects and the likelihood that designers produce erroneous contract documentation. Lack of attention to quality management during the design process has resulted in the notion of rework becoming entrenched in work practices, and consequently, less profit is being experienced [32], [70]. Contractors and subcontractors are also susceptible to omission errors, for example, quality, safety, and environmental management system constraints may not be strictly adhered to, and as a result, tasks or processes may need to be reworked.

\section{CAUSES OF ERROR}

Errors occur due to physiological and psychological limitations of humans [37]. It is a matter of contention whether individuals can justifiably be blamed for all errors, as making mistakes is an innate characteristic of human nature [61]. Human errors occur for various reasons, and therefore, different actions are needed to prevent or avoid the different sorts of error experienced in construction and resource engineering projects. Regardless of the skill level, experience, or training that individuals possess, errors and omissions may be made at any time [2], [8], [35], [49], [60], [75].

Reason [62] proffered that there is no one error taxonomy that can be used for all circumstances as different error classifications serve different needs. Despite Reason's [62] assertion, several classification schemes, however, have been put forward for identifying generic causes of error (e.g., [5], [43]) and are deemed useful for assessing potential risks in projects. For example, Rogge et al. [69] developed a tool to provide early warning of possible rework prior to construction, based on the underlying conditions that could contribute to its occurrence. Such conditions include the degree of design coordination that is undertaken, the extent of design schedule compression, and the regularity of engineering verifications. Similarly, Manavazhi [56] developed a probabilistic model that could be used to forecast the propensity of a project to encounter design revisions. Design revisions are an inevitable and integral feature of the design process; therefore, it is important that firms are able to put mechanisms in place to plan and manage them as they occur [55]. Design revisions that require rework arise due to errors, incomplete misinformation, and changes (e.g., those that are client initiated and unforeseen) and can have a detrimental effect on productivity, morale, designer attitudes, and the overall profitability of the design practice [55].

An error can arise due a number of reasons.

1) Mistake - an error occurs as a result of ignorance of the correct task or the correct way to perform it. Reason [62] suggests that such mistakes can be either ruleor knowledge-based. With respect to rule-based errors, a practitioner may simply misapply a rule that has worked in a previous situation because they failed to notice contradictions. Alternatively, a bad rule that has remained uncorrected in a practitioner's collection of problem solutions could be applied to the situation at hand. Knowledgebased mistakes occur when the practitioner encounters a novel situation that lies outside the range of their learnt problem solving routines. Kletz [48] refers to such mistakes as a mismatch, as they arise because they are beyond the physical or mental capability of an individual. When confronted with such a position, practitioners are often forced to resort to slow and effortful reasoning and as such susceptible to making errors [62]. This is because a practitioner can only attend to and manipulate one or two discrete items at a given time, and they have to reply on a mental model of the current situation that is inherently incomplete [61]. In addition, practitioners have a tendency to follow their instinct and select features of the world to support it, while neglecting contradictory evidence that presents itself before them.

2) Noncompliance - an error occurs because an individual decides not to carry out a task or not to carry it out the way instructed or expected. They are deliberate acts and may occur due to motivational problems (e.g., low morale, poor supervision, perceived lack of concern, etc.). Such errors occur in a regulated social context and the 
TABLE I

Processes INVOLVED IN OMITTING A NeCESSARy StEP [65]

\begin{tabular}{|c|c|c|}
\hline Level of Failure & Nature of Failure & Failure Type \\
\hline $\begin{array}{l}\text { Planning and intention } \\
\text { formation }\end{array}$ & $\begin{array}{l}\text { - A necessary item is unwittingly } \\
\text { overlooked } \\
\text { - The item is deliberately left out of } \\
\text { the action plan }\end{array}$ & Violation \\
\hline $\begin{array}{l}\text { Intention storage in } \\
\text { prospective memory }\end{array}$ & $\begin{array}{l}\text { - The intention to carry out the } \\
\text { action(s) is not recalled at the } \\
\text { appropriate time }\end{array}$ & Lapse \\
\hline Action execution & $\begin{array}{l}\text { - The actions do not proceed as } \\
\text { intended and a necessary item is } \\
\text { unwittingly omitted from the } \\
\text { sequence }\end{array}$ & Slip \\
\hline Monitoring & $\begin{array}{l}\text { - The actor neither detects nor } \\
\text { corrects the prior omission }\end{array}$ & Slip or violation \\
\hline
\end{tabular}

prevention of which must be addressed through motivational and organizational remedies vis-à-vis improving the quality and delivery of information within an organization and project.

3) Slips and lapses of attention - an error that occurs as a result of forgetfulness, habit, or similar psychological issues. Here the error typically occurs at the level of execution and generally involves routine tasks in familiar surroundings. Reason [62] suggests such errors are associated with some form of attention capture, either distraction from the immediate surroundings or a preoccupation with something.

Omission errors arise when the mental process of action control is subjected to strain or distraction [65]. Action control involves at least four stages, planning, intention storage, execution, and monitoring, and a problem in any one of these processes may lead to an omission occurrence (Table I).

Determining the exact cognitive processes that are involved in omitting a crucial task is an arduous process, as even the error maker finds it difficult to identify the cause of a specific failure. Reason [65] suggests that to reduce the incidence of omission errors in a process, there needs to be a shift away from examining the underlying mental processes involved to those characteristics most likely to afford them. Several authors have identified a number of task properties that are likely to increase the probability that a particular task in a process will be omitted, as depicted by the following examples.

1) The greater the informational loading of a particular task, i.e., items within a step are more likely to be omitted when the demands imposed upon short-term memory are higher [59].

2) Procedural steps that are functionally isolated, i.e., ones that are not obviously cued by preceding actions nor follow in a direct linear succession from are more likely to be left out [65].

3) Recursive or repeated procedural steps are particularly prone to omission. In the case where two similar steps are required to achieve a particular goal, it is the second of these two steps that is most likely to be neglected [39].

4) Steps in which the item to be acted is concealed is liable to omission [65].

5) Steps located near the end of a task sequence are likely to be omitted. Such premature exits are due, in part, to the actor's preoccupation with the next task, particularly, when the current activity involves largely routine tasks [63].

6) Tasks that involve planned departures from standard operating procedures or from habitual action sequences are liable to strong intrusions in which the currently intended actions are supplanted by a more frequently used routine in that context, and thus, omitted [65].

A number of the aforesaid omissions may occur simultaneously and be combined into a single task. When this happens, the effects are additive and the result is a recurrent error trap for those involved [63].

\section{A. Error Cycle}

Errors are often not immediately identifiable and only transpire after a period of incubation in the system [18], [25]. After sometime these errors are detected and rework is identified which increases the amount of work to be undertaken by staff [25], [67], [68]. The degree of rework required will be dependent on how long the error has remained undetected. For instance, a dimensional error or spatial conflict contained within design documentation may not arise until the project is being physically constructed on-site. If the error necessitates a major change to be undertaken then all the perceived progress prior to the error occurring may be considered wasted. Addressing the error may generate more work for individuals and the possibility of more errors being generated. Poor rates of progress occur mainly when staff involved in the documentation process either leave the design organization (staff turnover) or become unavailable (due to illness or recreational leave) and replacement staff are needed to complete the documentation process. Discontinuity of design staff can have a significant impact on design process performance. This is because all project knowledge and information accrued by each staff member cannot be readily passed directly from one individual to the next, even if a hand-over "transient" period (and/or debriefing) occurs. Even staff recruited from the same office cannot acquire sufficiently detailed project knowledge immediately after they commence work on the project. In practice, documentation activities are executed at varying levels (depending upon the skill and experience of the individual designer) and as a result this is also likely to impact on documentation quality.

When a project begins to be delayed or there is a potential for delay, then management invariably focus on the resource and productivity to deliver the project successfully. Cooper [25] suggests that the quality and the error discovery rate are the most important factors that should be considered. Simply throwing more resources at the project does not solve the fundamental problems; a more effective approach should be to reduce the number of errors or at least the time taken over their detection. The undertaking of a design audit, verification and review are practices that can be adopted to minimize the occurrence of errors (particularly those of dimensional nature).

Errors occur because of a complex array of interactions, and therefore, attempting to isolate a singular causal variable is deemed to be an unfitting strategy to undertake [52]. Once an understanding of the archetypal nature and underlying dynamics 
TABLE II

SAMPLE CHARACTERISTICS BY POSITION AND INDUSTRY SECTOR

\begin{tabular}{|c|c|c|c|}
\hline \multirow[t]{2}{*}{ Position Type } & \multicolumn{3}{|c|}{ Industry Sector } \\
\hline & $\begin{array}{c}\text { Oil \& Gas } \\
(\mathrm{n}=20)\end{array}$ & $\begin{array}{l}\text { Mining } \\
(\mathrm{n}=18)\end{array}$ & $\begin{array}{c}\text { Construction } \\
(\mathrm{n}=21)\end{array}$ \\
\hline Operations Manager & 2 & 2 & - \\
\hline Project Manager & 12 & 4 & 5 \\
\hline Structural Engineer & 3 & 3 & 4 \\
\hline Procurement Manager & - & 2 & - \\
\hline Quantity Surveyor & 1 & - & 4 \\
\hline Architect & - & - & 8 \\
\hline Mechanical Engineer & 2 & 5 & - \\
\hline Engineering Manager & - & 2 & - \\
\hline
\end{tabular}

of errors is acquired, then error reduction (measures designed to limit the occurrence of errors) and error containment (measures designed to enhance the detection and recovery of errors, as well as minimize their adverse consequences) strategies can be implemented in projects [53].

\section{RESEARCH APPROACH}

To determine the latent conditions that contribute to omission errors, an exploratory research approach was adopted. This was because limited research pertaining to the causal ascription of omission errors has been undertaken within the domain of construction and resource engineering projects. Causal modeling, an inherent feature of system dynamics, was used to construct a systemic causal model of omission errors. A similar approach has been used to examine claims [24], the rework cycle [25], the causes of delays and disruption [1], the impact of client behavior on project performance [68], the effects of scope on project performance [26], the cost and time performance of design and build projects [27], and the causes of design-induced rework [53]. Causal modeling can be used to provide managers with the necessary insights about the interdependencies and behavior between key variables that can contribute to omissions so that learning and process improvements can be made to future projects [1], [30].

\section{A. Data Collection}

Fifty-nine in-depth interviews were conducted over a sixmonth period with a variety of personnel such as operations managers, project managers, engineering managers, and architects from the construction and resource engineering sector (Table II). Interviews were used as the mechanism to determine the causal nature of omission errors. Interviews were chosen as the primary data collection mechanism because they are an effective tool for learning about matters that cannot be observed. According to Taylor and Bogdan [73, p. 79], no other method "can provide the detailed understanding that comes from directly observing people and listening to what they have to say at the scene."

Construction and resource engineering firms from Melbourne, Perth, and Sydney were selectively sampled and invited to participate in the research so as to reduce the likelihood of duplicating experiences from the same project. Firms in the Top 20 for construction and resource engineering by turnover as per the Dun and Bradstreet listing were identified and those where the research team had a direct contact point were invited to participate in the research. The interviews were conducted at the offices of interviewees. Interviews were tape recorded and transcribed verbatim to allow for the nuances in the interview to be apparent in the text. The interviewees' details were coded to allow for anonymity, although all interviewees were aware that it might be possible to identify them from the content of the text. The format of the interviews was kept as consistent as possible following the themes associated with rework identified from the literature. Interviews were kept open using phrases such as "tell me about it" or "can you give me an example." The open nature of the questions allowed for avenues of interest to be pursued as they arose without introducing bias in the response. Notes were taken during the interview to support the tapes to maintain validity. Each of the interviews varied in length from $45 \mathrm{~min}$ to $2 \mathrm{~h}$. Interviews were open to stimulate conversation and breakdown any barriers that may have existed between the interviewer and interviewee.

\section{B. Data Analysis}

The text derived from the interviews was analyzed using QSR N5 (which is a version of NUD $*$ IST and combines the efficient management of nonnumerical unstructured data with powerful processes of indexing and theorizing) and enabled the development of themes to be identified. One advantage of such a software is that it enables additional data sources and journal notes to be incorporated into the analysis. The development and reassessment of themes as analysis progresses accords with the calls for avoiding confining data to predetermined sets of categories [72]. Kvale [50] suggests that ad hoc methods for generating meaning enable the researcher access to "a variety of common-sense approaches to interview text using an interplay of techniques such as noting patterns, seeing plausibility, making comparisons, etc." (p. 204)

Using NUD $*$ IST enabled the researchers to develop an organic approach to coding as it enabled triggers or categories of interest in the text to be coded and used to keep track of emerging and developing ideas [50]. These codings can be modified, integrated or migrated as the analysis progresses and the generation of reports, using Boolean search, facilitates the recognition of conflicts and contradictions. This process enabled the development of a causal model that was augmented by taxonomies developed by Busby and Hughes [18] to identify pathogens that emerged. Reason's [65] classification of "failure types" (i.e., mistake, violation, lapse, slip) was used to determine the reason for the occurrence of an omission error (Table I).

\section{ANATOMY OF OMISSION ERRORS}

The interviews revealed insights about participants and their experiences associated with omission errors in projects. Table II presents a summary of interviewees sampled by industry sector. From the interviews, a total of 85 omission error cases were derived from the interviewees' comments. For each of the 
TABLE III

COMMON PATHOGENS AND OMISSION ERRORS IDENTIFIED

\begin{tabular}{|c|c|c|c|c|c|c|}
\hline $\begin{array}{l}\text { Pathogen } \\
\text { Category }\end{array}$ & Description & $\begin{array}{l}\text { Omission Error } \\
\text { Cause Examples }\end{array}$ & $\begin{array}{c}\text { Failure } \\
\text { Type (e.g) }\end{array}$ & $\begin{array}{l}\text { Oil \& Gas } \\
(\mathrm{n}=28)\end{array}$ & $\begin{array}{l}\text { Quantity } \\
\text { Mining } \\
(\mathrm{n}=26) \\
\end{array}$ & $\begin{array}{c}\text { Construction } \\
(\mathrm{n}=31)\end{array}$ \\
\hline Practice & $\begin{array}{l}\text { Pathogens arising from } \\
\text { people's deliberate practices }\end{array}$ & $\begin{array}{l}\text { - Failure to undertake design } \\
\text { reviews } \\
\text { - Distribution of tentative } \\
\text { design documents }\end{array}$ & $\begin{array}{l}\text { Violation } \\
\text { Violation }\end{array}$ & 19 & 17 & 17 \\
\hline Task & $\begin{array}{l}\text { Pathogens arising from the } \\
\text { nature of task being performed }\end{array}$ & $\begin{array}{l}\text { - Engineer failed to detect and } \\
\text { corrects an omission in design } \\
\text { documentation } \\
\text { - Schedule pressure resulted in } \\
\text { disproportionate time } \\
\text { allocation for tasks }\end{array}$ & $\begin{array}{c}\text { Slip } \\
\text { Violation }\end{array}$ & 2 & 5 & 4 \\
\hline Circumstance & $\begin{array}{l}\text { Pathogen arising from the } \\
\text { situation or environment the } \\
\text { project is operating in }\end{array}$ & $\begin{array}{l}\text { Low design fees meant tasks } \\
\text { were deliberately left out } \\
\text { - Schedule pressure result in } \\
\text { some tasks not being recalled } \\
\text { at the appropriate time }\end{array}$ & $\begin{array}{l}\text { Violation } \\
\text { Lapse }\end{array}$ & 2 & 1 & 2 \\
\hline Convention & $\begin{array}{l}\text { Pathogens arising from } \\
\text { standards and routines }\end{array}$ & $\begin{array}{l}\text { - Re-use of existing } \\
\text { specification and design } \\
\text { solutions } \\
\text { - } \text { Failure to adhere to new } \\
\text { company polices }\end{array}$ & $\begin{array}{l}\text { Violation } \\
\text { Violation }\end{array}$ & 4 & 2 & 5 \\
\hline Tool & $\begin{array}{l}\text { Pathogens arising from a } \\
\text { characteristic of a technical tool }\end{array}$ & $\begin{array}{l}\text { - Inoperability with CAD } \\
\text { software applications (no } \\
\text { checking for inconsistencies) } \\
\text { - Simplification of tasks and } \\
\text { neglect for other aspects of } \\
\text { design }\end{array}$ & Violation & 1 & 1 & 3 \\
\hline
\end{tabular}

omission errors identified, the pathogen category [18] and failure type [65] were identified.

\section{A. Error Categorization}

Table III presents a categorization of pathogens, examples of omission errors, and the respective failure type. It can be seen that $53(62 \%)$ of errors were due to practice, $11(13 \%)$ task, 5 (6\%) circumstance, 11 (13\%) convention, and 5 (6\%) tool.

Table IV presents an example of a practice-based pathogen that was undertaken using a peer-review of design documentation for internal purposes (so as to reduce risk and not to examine how the mechanical engineering design married with the project's structural elements). This practice not only results in the review process being ineffective but is likely to lead designers into a false sense of security and perhaps aberrant to self-checking [18].

In Fig. 1, the causal path of a practice-based pathogen is depicted. Here, it can be seen that an array of practices contribute to the occurrence of an omission error. The practice of designing work based on tentative information, departing from established procedures, and underestimating the time for engineering design are common conditions with which design firms are confronted. The effects of adopting such practices can lead to higher demands being placed on project personnel (e.g., stress and anxiety), conflict, and naturally, increased project time and cost.

In terms of tasks, the causes of omissions are related to designers and project personnel being placed under increasing pressure to complete their tasks within a specified time frame. Unrealistic demands and constraints were deemed to have been imposed on project personnel, which often resulted in tasks being "unwittingly" overlooked or omitted from a predetermined sequence. For example, in Table IV, project personnel were confused about whose role it was to order materials. This situation arose because the engineering manager had not confirmed with the procurement personnel the required specification for some offshore equipment that was required. Without the confirmation, no order could be placed. Yet, the procurement personnel simply forgot to follow up with the engineering manager and without checking assumed that an order had been placed.

Many of the underlying conditions that contribute to an omission are interdependent, and in many instances, isolating a specific pathogen proved difficult, particularly, in terms of circumstance and convention (Table IV). The issue of design fees was identified by interviewees in the construction sector as a factor contributing to an omission and design-related rework. Lower design fees juxtaposed with a "stretched" design and documentation schedule invariably resulted in tasks such as design reviews, checks, and verification being omitted. Moreover, to maximize fees and save design time, the existing design details and specification are reused, which may result in having a design that is inappropriate for its intended purpose.

Table III identifies an example of an omission error and how it was classified in terms of failure type. Of the 85 omission cases identified, violations accounted for 51 (60\%) slips 14 (16\%), lapses $13(15 \%)$, and mistakes 7 (8\%). Many of the violations identified were simply committed with the intention of increasing operational efficiency. Firms cannot and should not tolerate disregard for established procedures. The consequences of following such a course of action could be disastrous, not only 
TABLE IV

EXAMPLES OF INTERVIEWEE COMMENTS AND OMISSION ERRORS

\begin{tabular}{|c|c|c|}
\hline Practice & $\begin{array}{c}\text { Omission Error } \\
\text { Type }\end{array}$ & Interviewee Comment \\
\hline Design Fees & $\begin{array}{l}\text { - Informational overloading } \\
\text { - } \quad \text { Task sequence omitted } \\
\text { - } \begin{array}{l}\text { Procedural steps that are } \\
\text { functionally isolated }\end{array}\end{array}$ & $\begin{array}{l}\text { "For detailed design you can to pay lump sum for } \\
\text { certain parts of the design. There is always a lot of } \\
\text { pressure on the consultants to be competitive either } \\
\text { through minimum target man-hours, or through the } \\
\text { man-hour rates. Consultants tend to recover that by } \\
\text { increasing scope through claiming for changes in the } \\
\text { design. They often "take short cuts" when they feel } \\
\text { they are not getting a good fee. If they work on a lump } \\
\text { sum basis there is always a lot of pressure on total } \\
\text { number of man hours required to do the work and if } \\
\text { they need more man hours then as they have to deliver } \\
\text { within the lump sum so their way to save money is by } \\
\text { reducing what they pay their people. It is only under } \\
\text { fully reimbursable type of contract where you can take } \\
\text { that kind of pressure away. You need some idea how } \\
\text { much a project is going to cost you - the cost of blank } \\
\text { cheque approach is high to clients". }\end{array}$ \\
\hline Planning & - Informational overloading & $\begin{array}{l}\text { "Well...a number of reasons....If you look at where } \\
\text { we are today we are almost } 70 \% \text { of the way through } \\
\text { the project, running almost } 10 \% \text { behind. The reason } \\
\text { for the delay [is] late placement of purchase orders for } \\
\text { some materials, late delivery of some materials; } \\
\text { somebody forgot to place an order or assumed } \\
\text { someone else going to do it. Engineering is } \\
\text { progressing on track and if you look at the work off- } \\
\text { shore, we're also behind work off-shore. The reason } \\
\text { we are behind work off-shore is due to errors and the } \\
\text { subsequent rework". }\end{array}$ \\
\hline $\begin{array}{c}\text { Client } \\
\text { Demands }\end{array}$ & - Task sequence omitted & $\begin{array}{l}\text { "But in practice you don't have time to do that, it's } \\
\text { just not possible, as you try to meet the schedule, and } \\
\text { so you end up taking some short cuts .....You } \\
\text { compromise if you like" }\end{array}$ \\
\hline $\begin{array}{l}\text { Audits, } \\
\text { Verifications } \\
\text { and Reviews }\end{array}$ & $\begin{array}{l}\text { - Task sequence omitted } \\
\text { - Procedural steps that are } \\
\text { functionally isolated }\end{array}$ & $\begin{array}{l}\text { "We carry peer reviews etc at various stages during } \\
\text { design and also during construction. However, when } \\
\text { schedule (perhaps due to a major re-design) becomes } \\
\text { critical we sometimes skip these stages and try to } \\
\text { manage the subsequent risks that could arise. When } \\
\text { we do peer reviews we bring someone in who is } \\
\text { external to the project that has the right level of } \\
\text { experience to sit down and review the proposal and } \\
\text { making sure that based on their experience it all } \\
\text { appears to be logical and sensible as to where we are } \\
\text { going. In my experience though there have been times } \\
\text { when the peer-review has not worked - they tend to } \\
\text { gloss over and often blinded by their own experience". }\end{array}$ \\
\hline $\begin{array}{l}\text { Tentative } \\
\text { Design }\end{array}$ & $\begin{array}{l}\text { - Informational overloading } \\
\text { - Task sequence omitted }\end{array}$ & $\begin{array}{l}\text { "You get errors because there is a misunderstanding } \\
\text { (or lack of knowledge) by the fabricator of the design. } \\
\text { Not that the design is wrong but the way the fabricator } \\
\text { reads the design information might be different from } \\
\text { the way the designer meant it to be. In this case, we } \\
\text { were under pressure to finish a number tasks, and } \\
\text { certain things were 'basic' items had been missed off } \\
\text { the drawings and we expected the fabricator to pick } \\
\text { this up - he didn't. It was our fault really }\end{array}$ \\
\hline
\end{tabular}

in terms of increased project costs and time but areas of safety and design integrity. There are several compelling reasons for this. One is, of course, that standardization of operations cannot be achieved with idiosyncratic adherence to procedures.

\section{B. Causal Model of Omission Errors}

A detailed analysis of the interview data enabled the researchers to determine the archetypal nature and underlying dynamics of errors, and thus, develop a systemic causal model (Fig. 2). Fig. 2 identifies the common pathogens and circumstances that can promote an active failure to arise. Client requirements and the fees and margins of designers, consultants, and contractors were issues that influenced the planning and resource allocation and the subsequent workload of individuals. More often than not in projects, individuals and teams are given excessive workloads that require them to work longer hours in order to meet schedule. Consequently, individuals are subjected to increased levels of workplace stress and subjected to information overload that can affect short-term memory of individuals (Table IV). This can result in a task deviation occurring through a lapse or slip.

Procedures such as checking are simply overlooked or not given the due attention that is required when pressure to "get the job done" is exerted. Views from respondents revealed that it is often taken for granted that if there are "omissions" and they 


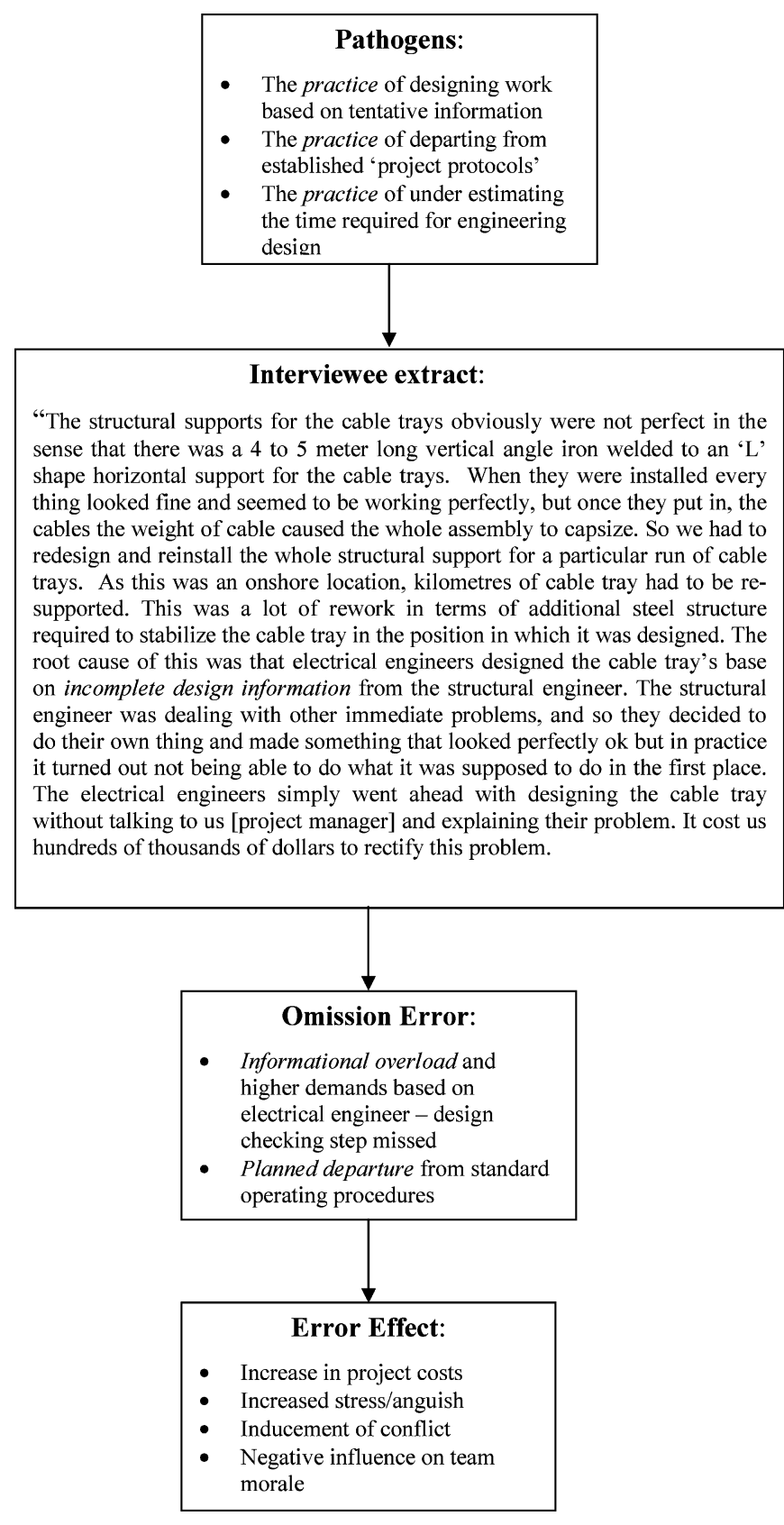

Fig. 1. Causal path: Pathogen and omission error.

cannot be readily detected, then they will be picked up later in the project. The longer an error goes undetected, the likelihood of significant rework occurring increases that can impact cost and schedule. It was suggested by an engineering manager that a parochial attitude of "she'll be right" was prevalent in many projects, and thus, contributed to the establishment of complacency. This was also identified as occurring in several instances by project managers on-site in construction and resource projects. Another interviewee stated that some engineers on-site often do not adhere to company quality procedures/standards and fail to complete the required documentation. Only when noncompliance is issued or an audit is undertaken that they begin to do what they are supposed to do. Then, after a period, the engineers on-site tend to go back to their original modus operandi. It was suggested by the project manager that some form of penalty could be issued for continually adhering to noncomplaint practices or some form of educational program explaining why procedural compliance was necessary should be undertaken.

When projects were subjected to fast-tracking (overlapping of design and construction activities), then it was found that the reuse of design details and specifications by architects and engineers were approaches used to minimize their workload and the production of a tentative design. This can lead to incomplete information with regard to design. The effects of having tentative design information are compounded further when organizations use differing technology and software applications that are partly incompatible (interoperability). Simple, pragmatic considerations such as checking for design inconsistencies are overlooked due to an "unhealthy" overreliance on the software applications output.

Ambiguous communication, such as not providing clear direction and information on what, when, and how a task is to be completed, can result in tasks being omitted. This was clearly the case in the example presented in Table IV, when there was a misunderstanding about the late placement of purchase orders. Interruptions to tasks being undertaken due to rework, design changes, or sequencing of tasks may result in an individual forgetting what they were supposed to do and skip particular steps because they have been delayed.

\section{ERROR MANAGEMENT}

Identification of the underlying causes of omission errors can assist with the development of error management strategies. Traditional quality control methods identify variation as nemesis in a process. The control of variation by itself can never achieve the significant low nonconformance levels that are expected by organizations and those required in projects. Mistakes are the most common cause of error in health care and industrial environments [40]. Excessive product and process complexity have been reported as being the underlying contributors to errors. Projects in the resource and construction engineering are typically complex and the pressures associated with satisfying clients and stakeholders are inexorable for those organizations given the responsibility for the delivery of a project. Invariably, pressures associated with the timely delivery of projects (e.g., processing plants, offshore platforms, roads, hospitals, schools, etc.) are of central concern to industry clients. Key drivers facilitating the need for the timely delivery of projects are the increasing costs of capital, increased shareholder expectations for a return on investment, the need to be responsive to market needs, environmental concerns, and the requirement for physical infrastructure to meet the growing needs of an increasing population.

The pressures associated with "stretched" design and construction schedules and the current skills shortage in Australia have often contributed to design-related documentation not being completed before the commencement of construction [11]. Increased job demands and information overload can lead to 


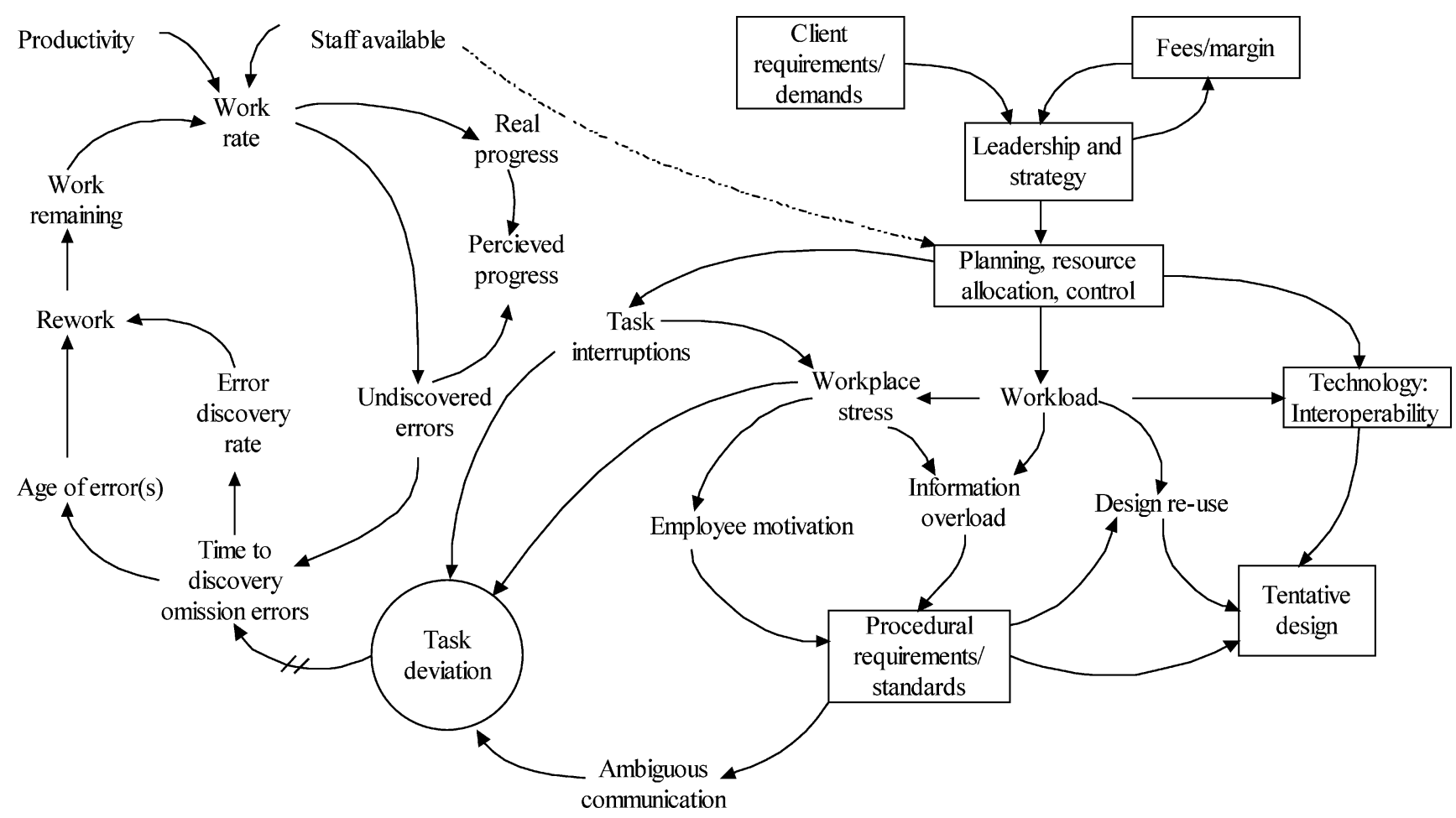

Fig. 2. Systemic causal model of pathogens and omission errors.

the occurrence of mistakes, yet the evidence presented clearly reveals that procedural violations are the primary contributors to omission errors, especially with design consultants. It would appear that individuals are purposefully not taking the appropriate time to check for errors.

Design consultants (such as architects and engineers) are expected to use reasonable and ordinary care in the practice of their profession and their responsibilities are, in part, defined by social ascription [33]. From a legal perspective, this is well known among the professions but clients are not always aware or made aware of this [34]. Architects and engineers cannot guarantee the results of their service. Their liability for errors and omissions, however, can be "determined by whether they have performed their services with the standard of care consistent with other professional designers within their community" [34]. Once clients are aware of their designer's obligation they often find it difficult to comprehend what is meant by standard of care [19]. Usually, this is left up to a court of law or a panel of experts once a breach of the standard of care is identified, but this can be a long and tedious process for clients with no guarantee of a successful outcome (e.g., [19]). Even when a standard of care is agreed upon precontract, any financial recovery may hinge on whether the mistake was an error (mistakes made by the designer) or omission (omitted from the contract).

\section{A. Reducing Omissions: Violations, Slips, Mistakes, and Lapses}

The human error problem can be viewed at two levels: the person approach and the system approach [64]. The person approach focuses on the errors of individuals, blaming them for forgetfulness, inattention, carelessness, poor motivation, and negligence. The system approach concentrates on the conditions under which individuals work and tries to build defences to avert errors or mitigate their effects.

The person approach focuses on the acts such as procedural violations that cause the error. Under the auspices of this approach, individuals are targeted and blamed for an error occurrence as it is deemed to be more "emotionally satisfying than targeting institutions" [64]. Essentially, individuals are viewed as having a choice between adopting error free or erroneousbased behaviors. If an error occurs, then it is obvious that an individual is responsible and so effort is spent trying to uncouple a person's acts from organizational liability.

The types of errors that continually arise in projects tend to be similar in nature, and as a result, "recurrent error traps" materialize. For example, it has been demonstrated that failure to undertake procedural tasks during the design process [3], [4], [16], and continual design reuse [14] are leitmotiv's that emerge as practices contributing to omission errors. The work practices implemented by organizations can provoke similar errors, regardless of the skills and experiences of the people involved in a project.

The pathogens that are likely to provoke omissions were identified in Table IV. An organization's immediate attention should focus on the task and the identification of appropriate reminders/checks so that lapses, slips, mistakes, or even violations do not occur, especially during the preparation of contract documentation. Task analysis involves decomposing an activity or procedure into a meaningful number of discrete steps. This is not a particularly difficult process, but can be time consuming for organizations, though those that have a quality assurance system in place would invariably have a stepwise process protocol 
documented and in place. It is, therefore, necessary to be selective in choosing the procedures for omission management. The most obvious basis for selection is the criticality of the task; would the omission of a particular task adversely influence project performance or design integrity? Should the consequences of such omissions be severe, then this would warrant the use of suitable reminders to undertake the task at hand. Omission-based strategies that can be used include [65]: notes and post-its, dairies, lists, getting others to act as reminders, mental checking, and mental rehearsal. While such strategies can be effective for addressing slips and lapses, and possibly even mistakes, they are ineffectual for preventing individuals from purposefully taking short cuts or missing out a process altogether.

Purely focusing on blaming an individual or attacking their ability to perform tasks may have detrimental consequences to learning and error reduction. Causal ascription after an error occurrence is deemed necessary to obtain knowledge about events for the purpose of undertaking subsequent action [46]. Assigned causes can lead to considerable differences in behavior [76]. It has been shown that error causes such as lack of effort are less desirable than "lack of ability," as they lead to constructive rather than destructive behavior [31]. Behavior after error occurrence is influenced by the presentation of positive error heuristics, for example, "I made an error; I can learn from this!" [36]. Such positive error heuristics are presented to facilitate emotional coping after error occurrence, thereby aiding people to consider that errors can also be interpreted as informative feedback [42]. It has been shown that error management training leads to more functional task behavior, such as more requests for assistance, less frustration, and better performance [58]. Behavior modification can occur at an individual level regarding omission errors due to mistakes, lapses, and slips. When an individual is deemed to be recalcitrant (e.g., due to pressures beyond their control) and "violations" arise, then behavior modification should be perfunctory through systemic intervention.

Postproject or retrospective reviews, undertaken at an organizational or project level, are fundamental to error management and learning, as individuals may not automatically learn from their own experience [14]. To learn, individuals need to test new experiences against existing knowledge, and then, consciously reflect upon what has transpired [14]. The knowledge that is acquired during the review is usually dispersed among several people and it is this accumulation of "collective knowledge" that can be used as an enabler to systemic intervention by changing the conditions under which the individual performs their tasks so that omissions are eschewed in future projects.

An organization's culture influences the behavioral practices adopted by individuals. Effective risk management in a project is dependent upon a culture of reporting being in place [20]. Such a culture is integral to those organizations that have openly embraced total quality management (TQM) or significant aspects thereof. Without a detailed analysis of errors that have occurred using techniques such as causal loop diagramming [53], Pareto analysis [44], and fault tree analysis [22], there is no way of determining the "recurrent error traps" and risks that may reside within an organization and the project system. When a reporting culture is embedded within an organization, then it is important that there be a collective understanding of where the line should be drawn between blameless and blameworthy actions [54]. The development of an organization and project culture based on "objectivity and learning" is needed in this case. Many construction organizations, for example, have not actively embraced learning and quality practices. Such practices are critical components of an effective continuous improvement program, which invariably aims to negate errors.

\section{CONCLUSION}

Omission errors are a problematic issue in construction and resource engineering projects. The competitive environment within which firms operate often results in shortcuts and procedural tasks being neglected in order to achieve the demands being imposed on them. Organizations and individuals tend to repeat such practices because they become complacent as there appear to be no direct consequences for their actions. Even when errors do arise, there appears to be no transfer of learning from previous experiences. This is because organizations operating in a project environment are subject to new demands and constraints by different client organizations. The causal model that has been presented can be used to provide project managers with a better understanding of the omission affording features inherent to projects, and therefore, aid them in identifying and implementing error containment and reduction strategies. The caveat to this is that no one strategy is a panacea for reducing omissions, but focusing on the reduction of violations and adhering to procedures and protocols is the first step that is required in this instance.

\section{ACKNOWLEDGMENT}

The authors would like to acknowledge the constructive comments provided by the three anonymous reviewers and the Associate Editor, Professor Jeff Pinto.

\section{REFERENCES}

[1] F. Ackermann, C. Eden, and T. Williams, "Modelling litigation: Mixing qualitative and quantitative approaches," Interfaces, vol. 27, no. 2, pp. 48$65,1997$.

[2] D. E. Allen, "Human error and structural practice," J. Build. Phys., vol. 18, no. 4, pp. 313-319, 1995.

[3] Andi and T. Minato, "Representing causal mechanism of defective designs: A system approach considering human errors," Constr. Manage. Econ., vol. 21, pp. 297-305, 2003a.

[4] Andi and T. Minato, "Design documents in the Japanese construction industry: Factors influencing and impacts on construction process," Int. J. Proj. Manage., vol. 21, pp. 537-546, 2003 b.

[5] Andi and T. Minato, "Representing causal mechanism of defective designs: Exploration through case studies," Constr. Manage. Econ., vol. 22, pp. 183-192, 2004.

[6] J. L. Ashford, The Management of Quality in Construction. London, U.K.: E \& F Spon, 1992.

[7] A. R. Atkinson, "The pathology of building defects: A human error approach," Eng., Constr. Archit. Manage., vol. 9, no. 1, pp. 53-61, 1998a.

[8] A. R. Atkinson, "Human error in the management of building projects," Constr. Manage. Econ., vol. 16, pp. 339-349, 1998b.

[9] A. R. Atkinson, "The role of human error in construction defects," Struct. Surv., vol. 17, no. 2, pp. 231-236, 1999.

[10] R. Amalberti and L. Wioland, "Human error in aviation," in Aviation Safety, H. M. Soekkha, Ed. Utrecht, The Netherlands: VSP, 1997, pp. 91-108. 
[11] B. D. Waldron, "Scope for improvement: A survey of pressure points in Australian construction and infrastructure projects," A Report Prepared for the Australian Constructors Association by Blake Dawson Waldron Lawyers, Sydney, Australia, 2006.

[12] D. Blockley, Engineering Safety. London, U.K.: McGraw-Hill, 1992.

[13] J. L. Burati, J. J. Farrington, and W. B. Ledbetter, "Causes of quality deviations in design and construction," J. Constr. Eng. Manage., vol. 118, no. 1, pp. 34-49, 1992.

[14] J. S. Busby, "An assessment of post project reviews," Proj. Manage. J., vol. 30, no. 3, pp. 23-29, 1999.

[15] J. S. Busby, "Error and distributed cognition in design," Des. Stud., vol. 22, pp. 233-254, 2001a.

[16] J. S. Busby, "Adaptation failures that cause error in technical organisations," Hum. Syst. Manage., vol. 20, pp. 301-312, $2001 \mathrm{~b}$.

[17] J. S. Busby and M. Coeckelbergh, "The social ascription of obligations to engineers," Sci. Eng. Ethics, vol. 9, pp. 363-376, 2003.

[18] J. S. Busby and E. J. Hughes, "Projects, pathogens, and incubation periods," Int. J. Proj. Manage., vol. 22, pp. 425-434, 2004.

[19] J. C. Chapman, "Collapse of the Ramsgate walkway," Struct. Eng., vol. 76, no. 1, pp. 1-10, 1998.

[20] C. Chapman and S. Ward, Project Risk Management: Processes, Techniques and Insights, 2nd ed. Chichester, U.K.: Wiley, 2003.

[21] E. W. L. Cheng, H. Li, P. E. D. Love, and Z. Irani, "A learning culture for strategic partnering in construction," Constr. Innov., vol. 4, no. 1, pp. 53-65, 2004.

[22] S. O. Cheung and T. W. Yiu, "Are construction disputes inevitable?" IEEE Trans. Eng. Manage, vol. 53, no. 3, pp. 456-470, Aug. 2006.

[23] Construction Industry Development Agency (CIDA), Measuring Up or Muddling Through: Best Practice in the Australian Non-Residential Construction Industry. Sydney, Australia: Construction Industry Development Agency and Masters Builders Australia, 1995.

[24] K. G. Cooper, "Naval shipyard production: A claim settled and a framework built," Interfaces, vol. 10, no. 6, pp. 30-36, 1980.

[25] K. G. Cooper, "The rework cycle: Benchmarking for the project manager," Proj. Manage. J., vol. 24, no. 1, pp. 17-22, 1993.

[26] S. Chritamara, S. O. Ogunlana, and N. N. Bach, "Investigating the effect of initial scope establishment on the performance of a project through system dynamics modelling," Eng. Constr. Archit. Manage., vol. 8, no. 5/6, pp. 381-392, 2001.

[27] S. Chritamara, S. O. Ogunlana, and N. N. Bach, "System dynamics modelling of design and build projects," Constr. Innov., vol. 2, pp. 269-295, 2002.

[28] D. Cusack, "Implementation of ISO 9000 in construction," presented at the ISO 9000 Forum Symp., Gold Coast, Australia, Nov. 1992.

[29] J. E. Diekmann and J. C. Nelson, "Construction claims: Frequency and severity," ASCE J. Constr. Eng. Manage., vol. 111, no. 1, pp. 74-81, 1985.

[30] C. Eden, T. Williams, and S. Howick, "The role of feedback dynamics in disruption and delay on the nature of disruption and delay (D\&D) in major projects," J. Oper. Res. Soc., vol. 51, no. 3, pp. 291-300, 2000.

[31] F. Fösterling, "Attributional retaining: A review," Psychol. Bull., vol. 98, pp. 495-512, 1985.

[32] J. Gardiner, "Management of design documentation, where do we go from here?" in Construction and Management, Recent Advances, R. R. Wakefield and D. G. Carmichael, Eds. Rotterdam, The Netherlands: Balkema, 1994, pp. 113-118.

[33] A. Grunwald, "The application of ethics to engineering and the engineer's moral responsibility: Perspectives for a research agenda," Sci. Eng. Ethics, vol. 7, pp. 415-428, 2001.

[34] D. Guckert and R. King (2002, Sep./Oct.), "Who pays for the architect's mistakes?" Facil. Manage. [Online]. Available at: www.appa.org

[35] E. Hagan and G. Mays, "Human factors engineering in the US nuclear arena," Nucl. Safety, vol. 22, pp. 337-346, 1981.

[36] D. Heimbeck, M. Frese, S. Sonnetag, and N. Keith, "Integrating errors into the training process. The function of error management instructions and the role of goal orientation," Pers. Psychol., vol. 56, pp. 333-361, 2003.

[37] R. L. Helmreich, "On error management: Lessons from aviation," $\mathrm{Br}$. Med. J., vol. 320, pp. 781-785, 2000.

[38] R. L. Helmreich and A. C. Merritt, Culture at Work: National, Organisational and Professional Influences. Aldershot, U.K.: Ashgate, 1998.

[39] D. Herrman, H. Weigartner, and A. Searleman, Memory Improvement: Implications for Memory Theory. New York: Springer-Verlag, 1992.

[40] C. M. Hinckley, Make No Mistake-An Outcome Based Approach to Mistake Proofing. New York: Productivity, 2001.
[41] G. D. Holt, P. E. D. Love, and H. Li, "The learning organisation: A paradigm for mutually beneficial strategic construction alliances," Int. J. Proj. Manage., vol. 18, no. 6, pp. 415-423, 2000.

[42] G. J. Homsma, C. V. Dyck, D. D. Gilder, P. L. Koopman, and T. Elfring, "Overcoming errors: A closer look at the attributional mechanism," $J$. Bus. Psychol., vol. 21, no. 4, pp. 559-583, 2007.

[43] N. W. Hurst, L. J. Bellamy, T. A. W. Geyer, and J. A. Astley, "A classification scheme for pipework failures to include human and socio-technical errors and their contribution to pipework failure frequencies," J. Hazard. Mater, vol. 26, pp. 159-186, 1991.

[44] K. Karim, M. Marosszkey, and S. Davis, "Managing subcontractor supply chain for quality in construction," Eng. Constr. Archit. Manage., vol. 13, no. 1, pp. 27-42, 2006.

[45] D. Kaminetzky, Design and Construction Failures: Lessons from Forensic Investigations. New York: McGraw-Hill, 1991.

[46] H. H. Kelley, Attribution in Social Interactions. Morristown, NJ: General Learning, 1971.

[47] M. M. Kumaraswamy, "Common categories and causes of construction claims," Constr. Law J., vol. 13, no. 1, pp. 21-34, 1997.

[48] T. Keltz, An Engineers View of Human Error. Rugby, U.K.: Institution of Chemical Engineers, 1985.

[49] J. Knocke, Post Construction Liability and Insurance. London, U.K.: E \& F Spon, 1992.

[50] S. Kvale, Interviews: An Introduction to Qualitative Research Interviewing. Thousand Oaks, CA: Sage, 1996.

[51] P. E. D. Love, "Influence of project type and procurement method on rework costs in building construction projects," ASCE J. Constr. Eng. Manage., vol. 128, no. 1, pp. 18-29, 2002.

[52] P. E. D. Love, D. J. Edwards, and Z. Irani, "A rework reduction model for construction," IEEE Trans. Eng. Manage., vol. 51, no. 4, pp. 426-440, Nov. 2005.

[53] P. E. D. Love, D. J. Edwards, and Z. Irani, "Forensic project management: An exploratory examination of the causal behaviour of design induced rework," IEEE Trans. Eng. Manage., vol. 55, no. 2, pp. 234-247, 2008.

[54] D. Marx, Maintenance Error Causation. Washington, DC: Federal Aviation Authority, Office of Aviation Medicine, 1999.

[55] M. R. Manavazhi and Z. Xunzhi, "Productivity orientated analysis of design revisions," Constr. Manage. Econ., vol. 19, no. 4, pp. 379-391, 2001.

[56] M. R. Manavazhi, "Assessment of the propensity for revisions in design projects through the dichotomous characterisation of designer effort," Constr. Manage. Econ., vol. 22, no. 1, pp. 47-54, 2004.

[57] R. E. Melchers, "Human error in structural design tasks," ASCE J. Struct. Eng., vol. 115, no. 7, pp. 1795-1807, 1989.

[58] C. R. Nordstrom, D. Wendland, and K. B. Williams, “'To err is human': An examination of the effectiveness of error management training," $J$. Bus. Psychol., vol. 12, pp. 269-282, 1998.

[59] D. A. Norman, The Psychology of Every Day Things. New York: Basic Books, 1988.

[60] D. Orndoff, "Errors and omissions: Fertile ground for high costs," Mil. Eng., vol. 506, pp. 107-109, 1986.

[61] J. Reason, Human Error. Cambridge, U.K.: Cambridge Univ. Press, 1990.

[62] J. Reason, "Safety in the operating theatre-Part 2: Human error and organisational failure," Anaesth. Crit. Care, vol. 6, pp. 121-126, 1995.

[63] J. Reason, "How necessary steps in a process get omitted: Revising old ideas to combat a persistent problem," Cogn. Technol., vol. 3, pp. 24-32, 1998.

[64] J. Reason, "Human error: Models and management," Br. Med. J., vol. 320, pp. 768-770, 2000.

[65] J. Reason, "Combating omission errors through task analysis and good reminder," Qual. Saf. Health Care, vol. 11, pp. 40-44, 2002.

[66] A. Robinson-Fayek, M. M. Dissanayake, and O. Campero, Measuring and Classifying Construction Rework: A Pilot Study, AB, Canada: Department of Civil and Environmental Engineering, Construction Owners Association of Alberta, AB, Canada, 2003.

[67] A. Rodrigues and J. Bowers, "The role of system dynamics in project management," Int. J. Proj. Manage., vol. 14, no. 4, pp. 213-220, 1996.

[68] A. Rodrigues and T. M. Williams, "System dynamics in project management: Assessing the impacts of client behaviour on project performance," J. Oper. Res. Soc., vol. 49, pp. 2-15, 1998.

[69] D. F. Rogge, C. Cogliser, H. Alaman, and S. McCormack, An Investigation of Field Rework in Industrial Construction (RR153-11). Austin, TX: Construction Industry Institute, 2001. 
[70] G. Rounce, "Quality, waste, and cost consideration in architectural building design management," Int. J. Proj. Manage., vol. 16, no. 2, pp. 123-127, 1998.

[71] J. W. Senders and N. P. Moray, Human Error: Cause, Prediction and Reduction. Hillsdale, NJ: Erlbaum, 1991.

[72] D. Silverman, Interpreting Qualitative Data. $\quad$ London: Sage, 2001.

[73] S. J. Taylor and R. Bogdan, Introduction to Qualitative Research Methods, 2nd ed. New York: Wiley-Interscience, 1984.

[74] P. A. Tilley and S. L. McFallan, Design and Documentation Quality Survey Comparison of Designers' and Contractors' Perspectives. BCE DOC 00/115. Melbourne, Australia: CSIRO Building, Construction and Engineering, 2000c.

[75] D. Wantanakorn, M. J. Mawdesley, and W. H. Askew, "Management errors in construction," Eng. Constr. Archit. Manage., vol. 6, no. 2, pp. 112-120, 1999.

[76] B. Weiner, An Attributional Theory of Motivation and Emotion. New York: Springer-Verlag, 1986.

[77] T. H. Wills and W. D. Willis, "A quality performance management system for industrial and construction engineering projects," Int. J. Qual. Rel. Manage., vol. 13, no. 9, pp. 38-48, 1996.

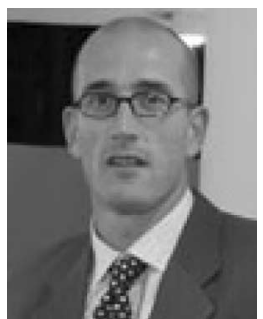

Peter E. D. Love received the M.Sc. degree in construction management from the University of Bath, Bath, U.K., in 1994, and the Ph.D. degree in operations management from Monash University, Melbourne, Vic., Australia, in 2001.

$\mathrm{He}$ is the inaugural Chair of Construction Innovation in the Department of Construction Management at Curtin University of Technology, Perth, WA, Australia. He has a multidisciplinary background and his current research interests include project management, engineering forensics, operations management, and information systems evaluation. He has coauthored/edited five books and has authored/coauthored over 300 internationally refereed research papers, which have appeared in leading international journals such as, the Journal of Management Information Systems, the European Journal of Operational Research, the Information and Management, the Information and Organisation, the European Journal of Information Systems, the IEEE TRANSACTION ON ENGINEERING MANAGEMENT, the International Journal of Production Economics, and the International Journal of Production Research.

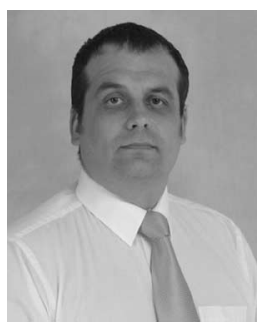

David J. Edwards is a Member of the U.K. Home Office's Plant Theft Action Group. He is on the technical and editorial panels of several international conferences and is a Peer Referee for 18 academic journals in his field. He is a Peer Referee for the Qualifications and Curriculum Authority, the Health and Safety Executive, the EPSRC, the U.K. Ministry of Defence, the Major Contractors Group, the Major Hire Companies Group, and the National Research Foundation (South Africa).

Since 2000, he has secured more than $£ 1000000$ of research funding. In 2005, he launched the Hand-arm Vibration Test Centre (HAVTEC) to mitigate the health risk associated with the operation of power tools. HAVTEC currently has over 12000 registered users. He is the author or coauthor of more than 100 peer-reviewed research papers, 14 textbooks, 2 textbook chapters, and 3 digital versatile disks (DVDs). His current research interests include plant and equipment management, project management, construction procurement, and health and safety.

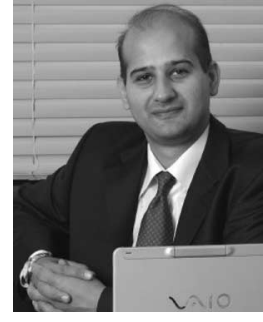

Zahir Irani is the Head of the Business School, Brunel University, Uxbridge, U.K. He leads a multidisciplinary group of international Ph.D. students that research information systems evaluation and application integration.

He has been the Hooker Distinguished Professor at McMaster University, Canada. He has also been a Visiting Professor at several Universities. He is the Editor-in-Chief of the established Journal of Enterprise Information Management and the European Editor of the Business Process Management Journal. He has coauthored/edited several books and has authored/coauthored over 300 internationally refereed research papers, which have appeared in leading international journals such as, the Journal of Management Information Systems, the European Journal of Operational Research, the Information and Management, the Information and Organisation, the European Journal of Information Systems, the IEEE TRANSACTIONS ON ENGINEERING MANAGEMENT, the International Journal of Production Economics, and the International Journal of Production Research. His current research interests include information systems evaluation, e-government, and operations and project management.

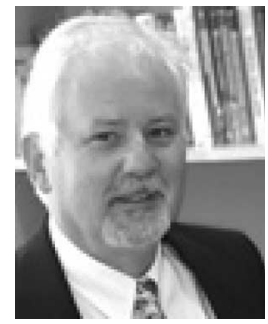

Derek H. T. Walker received the Master of Science degree from the University of Aston, Birmingham, U.K., in 1978, and the Ph.D. degree from RMIT University, Melbourne, Australia, in 1995. He is currently the Professor of Project Management and Program Director of the Doctor of Project Management (DPM) at the School of Property, Construction, and Project Management, RMIT University, Melbourne.

$\mathrm{He}$ has worked in various project management roles in the U.K., Canada, and Australia for 16 years before commencing his academic career in 1986 . He is the Editor of the Emerald Insight International Journal of Managing Projects in Business. He has written over 150 peer-reviewed papers and book chapters. His current research interests include innovation diffusion of information and communication technologies, knowledge management, project management, and project procurement systems. 